Károly Pálffy*, Mátyás Présing and Lajos Vörös

\title{
Diversity patterns of trait-based phytoplankton functional groups in two basins of a large, shallow lake (Lake Balaton, Hungary) with different trophic state
}

\section{Original publication in: Aquatic Ecology (2013) 47: 195-210}

MTA Centre for Ecological Research, Balaton Limnological Institute

3 Klebelsberg Kuno str., H-8237 Tihany, Hungary

*corresponding author: palffy.karoly@okologia.mta.hu, tel.: +36-87-448244, fax: +36-87-448006

\begin{abstract}
The application of functional approaches in understanding phytoplankton community-level responses to changes in the environment has become increasingly widespread in recent years. Eutrophication is known to cause profound modifications in ecosystem processes, however, the underlying relationships between environmental drivers and phytoplankton diversity and functioning are complex and largely unknown. Therefore, in the present study we investigated and compared the temporal diversity patterns of phytoplankton functional groups in the mesotrophic eastern and eutrophic western basin of the shallow Lake Balaton situated in Hungary. Diversity data were derived from taxonomic composition and biomass data corresponding to the years 2005-2006 and 2008-2009. With the use of cluster analysis phytoplankton species were classified into eight distinct groups representing different combinations of functionally relevant traits including greatest axial linear dimension, surface to volume ratio, photosynthetic pigment composition, $\mathrm{N}_{2}$-fixation, phagotrophic potential, growth form/complexity (unicell, filamentous, colony- or coenobium-
\end{abstract}


forming) and motility. Our results have revealed that there is a significant inverse relationship between the functional group diversity used in our study and trophic state (total phytoplankton biomass) as opposed to species diversity, where no correlation was observed. In addition, group evenness showed an even stronger negative correlation with trophic state, while species evenness yielded only a weak relationship. The observed variability in functional group diversity suggests that such an approach could provide an efficient means of revealing structural changes in phytoplankton communities, establishing new hypotheses and highlighting fundamental points in ecosystem functioning.

Keywords: phytoplankton, functional groups, diversity, trophic state, shallow lake 


\section{Introduction}

Determining biodiversity within different communities and relating its spatiotemporal changes to environmental variables and ecosystem processes such as nutrient cycling or primary production have long since constituted a focal point of ecological research. As for the conceptual background for defining diversity, there is increasing evidence that using diversity measures based on the role of species in a community can yield a better understanding of community patterns than traditional taxonomic analyses (Tilman et al. 1997; Weithoff et al. 2001.). The grouping of species into functional categories is not a recent idea, dating back more than 50 years (see Bahr (1982) for an early review), and its inclusion into diversity studies has been applied for a number of organism groups, such as terrestrial plants (Hector et al. 1999), fish assemblages (Erős et al. 2009) or crustacean zooplankton (Barnett et al. 2007).

In aquatic habitats, where phytoplankton is the main source of primary production, investigating algal assemblages from a functional point of view is likely to provide additional information about community-level processes (e.g. zooplankton grazing, nutrient transport) and responses to changes in the environment. So far, considerable efforts have been made to elaborate appropriate methods for explaining algal diversity patterns through functional classification, however, the possibility of interpreting the original idea in different ways has yielded a wide variety of approaches. Reynolds et al. (2002) proposed a freshwater phytoplankton classification scheme widely used in the last ten years (Padisák et al. 2009), which identifies the adaptive features of species as the key ecological driver and the main factor defining functional groupings. This system contains thirty-one associations, and species belonging to the same group can be frequently found in co-existence, moreover, they seemingly share similar tolerances and sensitivities. In this case, planktonic species are grouped in accordance with their regular occurrence in habitats with distinct characteristics, on the other hand, functional classification can also be realized in the context of various ecologically relevant attributes of the species present in a community. 
The work of Gaedke (1998) was among the first to consider functionality in revealing the variability of freshwater phytoplankton community composition in response to changing environmental variables by assigning species to different groups on the basis of their mixotrophic capabilities and edibility by zooplankton. While the former can serve as a competitive advantage under nutrient-depleted conditions (Raven 1997), the latter depends mainly, though not exclusively on cell size, which has been found to affect zooplankton grazing (Frost 1972; Perissinotto 1992; Lonsdale et al. 1996). At the same time, grazing is not the only community-level process influenced by cell size, cellular dimensions appear to have considerable effects on a range of physiological processes including growth, photosynthesis and respiration (Finkel 2001; Kagami and Urabe 2001) or nutrient uptake caused by the size-dependency of the surface-to-volume ratio (Hein et al. 1995). The unambiguous ecological relevance of organism size may provide an opportunity to explain phytoplankton patterns through its diversity (Paredes and Montecino 2011), however, in order to explore and to understand the complexity of processes on the community level, it is desirable to allow for all the species properties affecting any element of ecosystem functioning including material pools and fluxes or trophic interactions. Weithoff (2003) investigated the applicability of "plant functional types", a term originally used in terrestrial plant ecology, to phytoplankton communities, and specified six fundamental traits (size, $\mathrm{N}_{2}$-fixation, demand for silica, phagotrophy, motility and shape) considered to be useful for defining functional groups. All the past research efforts in certain respects related to phytoplankton functional ecology have promoted the outlining of a general trait-based concept, which comprises all the major ecological axes and associated species traits fundamentally influencing community processes (Litchman and Klausmeier 2008).

Our knowledge on how changes in the environment affect community structure and functioning through modifying the distribution of species traits is still very limited. In this respect eutrophication, i.e. the increase of nutrient supply resulting in algal blooms, which is a well-known environmental problem in aquatic habitats, is accompanied by profound modifications in ecosystem 
processes (primary production, community dynamics and trophic interactions in particular), however, the underlying causal relationships along the environment-diversity-functioning axis are complex and largely unknown on a community scale. Total phytoplankton biomass, as a measure of trophic state, has already been shown to significantly influence phytoplankton diversity (Jacobsen and Simonsen 1993; Duarte et al. 2006), on the other hand, trait-based approaches have the potential to shed light on the links between the observed effects on diversity and community functioning.

With this end in view, in the present study we investigated and compared temporal patterns in the abundance and diversity of phytoplankton functional groups in two distinct parts of the shallow Lake Balaton with different trophic state. Functional classification was based on a selection of different ecologically relevant physiological and morphological traits. Since trophic state can be expressed in terms of various variables, such as chlorophyll $a$ and total phosphorus concentration, we laid particular emphasis on the relationship between the most important physicochemical and biotic characteristics of the lake and functional group diversity. Besides determining the diversity of trait-based groups, we also compared its sensitivity as an index to that of a traditional measure of species diversity.

\section{Materials and methods}

\section{Site description and sample collection}

Lake Balaton (Hungary) is a 77-kilometer-long shallow lake with the largest surface area in Central Europe $\left(594 \mathrm{~km}^{2}\right)$ and an average depth of $3.3 \mathrm{~m}$. An important factor affecting planktonic communities within the lake is that owing to its shallowness and large, exposed surface area the whole water column is thoroughly wind-mixed on a regular basis.

Samples were taken in 2005-2006 and 2008-2009 biweekly or monthly in the mesotrophic eastern $\left(46^{\circ} 55^{\prime} 19.0^{\prime \prime} \mathrm{N}, 17^{\circ} 55^{\prime} 53.6^{\prime \prime} \mathrm{E}\right)$ and eutrophic western basin of the lake $\left(46^{\circ} 44^{\prime} 05.8^{\prime \prime} \mathrm{N}\right.$, 
$\left.17^{\circ} 16^{\prime} 32.0^{\prime \prime} \mathrm{E}\right)$. Eutrophication in Lake Balaton began at the end of the 1960 s resulting in a sudden increase of summer phytoplankton biomass, particularly in the western basin, with the dominance of filamentous $\mathrm{N}_{2}$-fixing cyanobacteria (Vörös and Nagy Göde 1993; Padisák and Szabó 1997). Due to restoration measures taken to reduce external nutrient loads this process has been impeded and reversed from the mid-1990s, but the trophic gradient from the eutrophic western basin to the mesotrophic eastern part has still remained characteristic, mainly because the only major river of the catchment area flows into the westernmost part of the lake.

We used a tubular water sampler in order to obtain samples representative for the whole water column. Water temperature was measured before each sampling. Photosynthetically active radiation along the water column was measured with a Li-Cor, Inc. Model LI 185B radiometer equipped with $2 \pi$ underwater sensor. Vertical extinction coefficient was determined on the basis of the BeerLambert law.

\section{Laboratory analysis}

Freshly collected samples were immediately transported into the laboratory for measuring chemical parameters, namely, total phosphorus (TP), chlorophyll $a$ concentration $(\mathrm{Chl} a)$ and total suspended solids content (TSS). TP was measured according to Gales et al. (1966). All the phosphorus forms were transformed into $\mathrm{PO}_{4}{ }^{3-}$ by dissolving the samples in $\mathrm{K}_{2} \mathrm{~S}_{2} \mathrm{O}_{8}$ for one hour at $121{ }^{\circ} \mathrm{C}$. Next, after adding $5.4 \%$ ascorbic acid and a reagent solution $\left(14 \% \mathrm{H}_{2} \mathrm{SO}_{4}, 3 \%\left(\mathrm{NH}_{4}\right)_{2} \mathrm{MoO}_{4}\right.$ and $0.34 \% \mathrm{C}_{4} \mathrm{H}_{4} \mathrm{KO}_{7} \mathrm{Sb}$ ) the absorbance of the mixture was measured at $890 \mathrm{~nm}$ using a SHIMADZU UV-VIS spectrophotometer. Total suspended solids content was determined gravimetrically after sample filtration on 0.4 pore size cellulose acetate filters. Chlorophyll $a$ concentration was determined spectrophotometrically after hot methanol extraction using the absorption coefficients determined by Wellburn (1994). 


\section{Taxonomic analysis and functional classification}

$50 \mathrm{~mL}$ aliquots of the samples were fixed with $50 \mu \mathrm{L}$ Lugol's iodine and stored at $5^{\circ} \mathrm{C}$ for microscopic analysis. Nano- and microplankton species composition and abundance were determined with an inverted microscope (Utermöhl 1958) at 400x magnification. The abundance of picophytoplankton was determined from freshly collected samples by epifluorescence microscopy based on the method of MacIsaac and Stockner (1993) at 1000× magnification using twin images with blue-violet and green excitation light obtained with a Nikon Optiphot 2 epifluorescent microscope and a SPOT RT camera. Biovolume and surface area of the observed taxa were calculated with the formulas of Hillebrand et al. (1999) using average species dimensions. The biomass of each species was calculated as the product of species abundance and biovolume assuming an average cell density of $1 \mathrm{~g} \mathrm{~cm}^{-3}$.

Seven different traits were chosen for the creation of functional groups: photosynthetic pigment composition, growth form/complexity, greatest axial linear dimension (GALD), surface to volume ratio $(s / v)$, ability to fix $\mathrm{N}_{2}$, phagotrophic potential and motility/buoyancy. According to their pigment composition, taxa were assigned to four different groups (as detailed in Graham et al. 2009): Cyanobacteria (chlorophyll $a$, phycobilins); Chlorophyta and Euglenophyta (chlorophyll $a$, chlorophyll $b$ ); Heterokontophyta, Dinophyta and Haptophyta (chlorophyll $a$, chlorophyll $c$ ); Cryptophyta (chlorophyll $a$, chlorophyll $c$, phycobilins). The second trait, growth form/complexity consisted of four types: unicellular, filamentous, colonies and coenobia. The consideration of GALD meant three different size classes: small cells under $5 \mu \mathrm{m}$, those between 5 and $25 \mu \mathrm{m}$ and larger cells above $25 \mu \mathrm{m}$. These threshold values were chosen based on the assumption that cells under $25 \mu \mathrm{m}$ are more sensitive to zooplankton grazing, while those under $5 \mu \mathrm{m}$ usually have particularly high surface to volume ratio. In the case of multicellular organisms, the GALD of the whole filament, colony or coenobium was taken into account. Motility/buoyancy was considered in three different forms: non-motile taxa, those possessing gas vacuoles allowing vertical migration and flagellated cells with the ability of free movement. 
Functional groups were determined by cluster analysis performed with the statistical program SYNTAX2000. Hierarchical clustering was performed using the group average (UPGMA) method, dissimilarities from mixed data were calculated with Gower's formula (Gower 1971, modified by Podani 1999). The dendrogram obtained from the cluster analysis served as the framework of our classification, i.e. one distinct branch corresponded to one functional group of species. Functional group diversity $\left(H_{f}\right)$ was calculated using the Shannon index:

$$
H_{f}=-\Sigma p_{i} \ln p_{i}
$$

where $p_{i}$ is the contribution of species $i$ to total biomass (Krebs 1998). The formula was modified to include the relative biomass of functional groups instead of species. Furthermore, evenness $(J)$ was determined using the following formula:

$$
J_{f}=H_{f} / H_{\text {fmax }}
$$

where $H_{\max }$ is the maximum value of diversity:

$$
H_{\text {fmax }}=\ln S
$$

where $S$ is the number of functional groups present in the community. In addition to functional group diversity, species diversity $(H)$ and evenness $(J)$ was also determined for comparison as described above.

\section{Statistical analysis}

Pearson's correlation coefficients were calculated to determine the relationship between diversity indices, functional group abundances and the environmental variables. Principal 
components analysis (PCA) was performed to reveal differences between the two basins of the lake using data on TP, TSS, $\mathrm{K}_{\mathrm{d}}, \mathrm{T}$, chlorophyll $a$ concentration, total phytoplankton biomass and functional group diversity. Statistical analyses were carried out in the software R 2.14.2. On certain occasions sampling for phytoplankton and for TP and TSS took place on different days, therefore these observations were omitted from the analysis.

\section{Results}

Total phosphorus (TP), chlorophyll a concentration and total suspended solids content (TSS)

There were marked differences between the two basins in respect of all the three variables. The boxplot of TP shows that while in the eastern part the upper and lower quartile is 20.5 and $31.3 \mu \mathrm{g}^{-}$

${ }^{1}$, respectively, in the western basin these values reached 30.8 and $53.9 \mu \mathrm{g} \mathrm{1^{-1 }}$ with a maximum above $85 \mu \mathrm{g} \mathrm{l}^{-1}$ (Fig. 1). Similar differences could be noted in terms of chlorophyll $a$ concentration, the quartile and maximum values of the western basin considerably exceeded those of the eastern part. Both TP and chlorophyll $a$ values confirm previous observations regarding the trophic state of Lake Balaton with a mesotrophic eastern and a eutrophic western part (Padisák and Reynolds 1998; Hajnal and Padisák 2008).

Total suspended solids content varied highly between 3 and $54 \mathrm{mg} \mathrm{l}^{-1}$ with values of the western basin covering the whole range, while those of the eastern basin concentrated mostly in the lower half (Fig. 2). Beside the spatial differences we also found a positive relationship between TP and TSS $\left(\mathrm{R}^{2}=0.4577\right)$.

\section{Phytoplankton functional groups}

Our cluster analysis applying the selected functional traits as variables yielded 8 distinct functional groups, which appeared as separate branches of the dendrogram around a dissimilarity 
level of 0.38 (Fig. 3). We briefly describe each group according to their basic characteristics and frequently occurring members.

Group 1. Large, non-motile cells

Algae of this group are chlorophytes and diatoms with large GALD, often exceeding $100 \mu \mathrm{m}$, and a s/v ratio between 0.22 and 3.33. Members comprise unicells, filamentous, colonial and coenobial forms alike. The unicellular diatoms Nitzschia acicularis and Fragilaria acus, the chlorophytes Closterium acutum, C. aciculare and Staurastrum paradoxum and the filamentous Aulacoseira granulata and Planktonema lauterbornii are the most abundant and frequently occurring species.

Group 2. Medium-sized, non-motile cells

This group contains unicellular diatoms and chlorophytes with unicellular, colonial or coenobial forms reaching a GALD of 6-25 $\mu \mathrm{m}$ and a s/v ratio similar to Group 1 in variability. Species of the genus Cyclotella are the dominant members, other species regularly present in the lake include colonial or coenobial chlorophytes, mainly Monoraphidium contortum, Botryococcus braunii, Oocystis spp., Crucigenia spp. and Desmodesmus spp.

Group 3. Large-celled flagellates with phagotrophic potential

Common characteristics of these algae are a GALD between 28 and $100 \mu \mathrm{m}$, a s/v ratio of 0.17-0.81 and the ability to move freely within the water column and to feed phagotrophically. The dinoflagellate Ceratium hirundinella is the most characteristic species within the group.

Group 4. Large, flagellated cells 
The only considerable difference between this group and the former one is the lack of phagotrophy, otherwise both the GALD and the s/v ratio are similar. Representative members come from the euglenophyte genera Euglena and Phacus and the colonial chrysophyte genus Synura.

Group 5. Medium-sized, flagellated cells

All the flagellated species with a GALD of $10-25 \mu \mathrm{m}$ belong to this branch. The $\mathrm{s} / \mathrm{v}$ ratio varies between 0.33 and 0.9 , being as low as those typical of larger flagellates. This group consists of cryptophytes and some green algae.

Group 6. Small unicells

Species of this branch can be divided into two subgroups. One of them consists of flagellated cells, whose average GALD and s/v ratio is $5 \mu \mathrm{m}$ and $1.2-1.3$, respectively. These algae included mainly chrysophytes and chlorophytes. The other subgroup contains chlorophytes and cyanobacteria of the pico size range with very low GALD $(1-1.5 \mu \mathrm{m})$ and extremely high s/v ratio (4-6.4).

Group 7. Large cyanobacterial filaments and colonies

Most of these taxa are filamentous with lengths between 50 and $1000 \mu \mathrm{m}$ and a s/v ratio ranging from 0.53 to 3.97 . $\mathrm{N}_{2}$-fixing cyanobacteria of this group (e.g. Aphanizomenon flos-aque, A. issatschenkoi and Cylindrospermopsis raciborskii) bear high ecological relevance in Lake Balaton, see discussed in a later section. The only colonial cyanobacterium genus suitable into this group is Microcystis with two species of negligible relative biomass. Each species possesses gas vacuoles, which enables them to move vertically within the water column.

Group 8. Medium-sized cyanobacterial coenobia 
The characteristic species belonging to this group is Snowella lacustris with a GALD of $20 \mu \mathrm{m}$ and a s/v ratio of 2.3 .

\section{Correlation between diversity and abiotic/biotic variables}

According to the correlation analysis the nature of the relationships for taxonomic diversity indices in most cases considerably differed from those revealed for the functional measures of diversity (Table 1). Temperature was the only variable, with which both $H$ and $H_{f}$ positively correlated to a similar extent. There was a significant negative correlation between total biomass, chlorophyll $a$ and $H_{f}$ and $J_{f}$, on the other hand, there was a weaker relationship with $J$ and no significant correlation with $H$. TP significantly positively correlated with $H$, although to a small degree, and there was a weak negative correlation between TP and $J_{f}$. No significant correlation was found between diversity and TSS and $\mathrm{K}_{\mathrm{d}}$.

Temporal changes in water temperature, phytoplankton biomass and functional group diversity

Characteristic temporal patterns of water temperature, total phytoplankton biomass, diversity and group abundances in 2005-2006 are shown in Fig. 4 and 5. Data obtained in 2008-2009 yielded basically similar trends. Water temperature within Lake Balaton varied between an average minimum of $0.3^{\circ} \mathrm{C}$ and a maximum of $25.7^{\circ} \mathrm{C}$ in the mesotrophic eastern basin, and between $0.4^{\circ} \mathrm{C}$ and $26.1^{\circ} \mathrm{C}$ in the eutrophic western basin. There was an apparent difference in total phytoplankton biomass between the two basins, mainly during the summer months until early autumn. While in the eastern part of the lake the summer maximum biomass varied from 2100 to $4200 \mu \mathrm{g} \mathrm{L}^{-1}$ (Fig. 4A), those of the western basin varied between 5800 and $14100 \mu \mathrm{g} \mathrm{L}^{-1}$ (Fig. 5A).

Coming from the nature of the Shannon formula, Fig. 4B and 5B demonstrate that functional group diversity values were always lower than those of species diversity. The temporal changes in the indices have revealed characteristic seasonal patterns, which appeared to be somewhat different in the two parts of the lake, and sometimes the rate and direction of change in functional group 
diversity substantially differed from that of species diversity. In the eastern basin these differences were less pronounced, winter phytoplankton was characterized by low functional and species diversity, while higher values generally occurred from the end of spring until mid-autumn with frequent fluctuations (Fig. 4B). Apart from this, in certain periods (e.g. October-November 2005, June 2006) the indices changed inversely. Diversity in the western basin showed a more complex pattern with easily discernible peaks and depressions (Fig. 5B). Summer maximum values were similar to those found in the other part of the lake, however, in August and September we regularly observed dramatic decreases in functional diversity resulting in values comparable to the winter minima. In the case of species diversity these decreases either occurred only gradually or in a considerably smaller degree. Substantial differences were also found in the winter of 2005-2006, when functional diversity decreased as opposed to the increase in species diversity.

The temporal patterns in the relative abundance of functional groups showed some general characteristics (Fig. 4C and 5C). Medium-sized non-motile cells (group 2) and flagellates (group 5), small unicells (group 6) and large cyanobacterial filaments and colonies (group 7) constituted the bulk of the biomass, with distinct periods of dominance. Group 2 dominated mainly from spring to early summer with additional peaks in winter and autumn in the eastern basin. Group 5 occurred mainly from autumn to late spring with higher biomass contribution in the western basin. No explicit pattern was observed in group 6, however, in the western basin their relative abundance dramatically decreased during the late summer bloom of group 7 (large cyanobacterial filaments and colonies), similarly to several other groups of the community. During these periods group 7 reached a biomass contribution of $80-90 \%$, which coincided with the peaks in total biomass. Largesized flagellates (groups 3 and 4) were mainly present in summer and autumn, species of group 3 reached high relative abundance only when group 7 did not dominate the community. The relative biomass of group 1 (large non-motile cells) and group 8 (medium-sized cyanobacterial coenobia) mostly remained below $10 \%$. Both groups showed low values or absence from December to early spring, and occasionally disappeared from the community during the summer peaks of group 7 . 
According to the correlation coefficients between the biomass of each functional group and the measured variables presented in Table 2, several groups had a significant correlation with chlorophyll $a$ concentration, particularly groups 1 and 7. Positive correlations with temperature were the strongest in groups 1 and 3, on the other hand, group 5 showed a rather weak, but significantly negative relationship. TSS had relatively weak correlations with groups 1, 2,3 and 7 . TP had the strongest correlation with groups 5 and $7 . \mathrm{K}_{\mathrm{d}}$ had a weak relationship with groups 4 and 7. Group 2 (medium-sized non-motile cells) had only weak correlation with TSS and TP, while Group 6 (small unicells) did not correlate with any of the variables.

\section{Changes in diversity and evenness as a function of biotic and abiotic variables}

When plotted against total phytoplankton biomass, functional group diversity $\left(H_{f}\right)$ and evenness $\left(J_{f}\right)$ values showed the significant relationships already found during the correlation analysis in contradiction to the lack of correlation with species diversity $(H)$ and evenness $(J)$ (Fig. 6). $H_{f}$ in the western basin changed in a decreasing trend toward higher biomass, and the same decrease was found for the trend in functional evenness with lower values particularly occurring above $5000 \mu \mathrm{g} \mathrm{L}^{-1}$. In the eastern basin, where biomass values never exceeded $4500 \mu \mathrm{g} \mathrm{L}^{-1}$, diversity and evenness didn't show any obvious relationship with total biomass.

The first two components of the PCA (PC1 and PC2) explained 76.9\% of the total variation of data (Fig. 7). Vectors from the PCA confirm the results of the correlation analysis, i.e. functional group diversity $\left(H_{f}\right)$ had a significant negative correlation with total phytoplankton biomass and chlorophyll $a$ concentration and a positive correlation with temperature. The direction of TP and $\mathrm{K}_{\mathrm{d}}$ demonstrates that there was no relationship between these variables and $H_{f}$. The PCA also shows that the points representing the eastern basin and those of the western part form two separate sets with little overlap. In the eastern basin observations with higher water temperature systematically had higher values of $H_{f}$, thus summer samples can be found on the negative side of PC 2 . On the 
other hand, high-biomass samples from the western basin yielded lower $H_{f}$, whereas summer samples with lower biomass were situated close to those of the eastern part.

\section{Discussion}

\section{The applicability of functional classification}

All the groups formed from species found in the phytoplankton of Lake Balaton by means of the cluster analysis can be characterized by some fundamental functional attributes, and on the strength of these group-specific trait values the groups can be easily distinguished. As already mentioned, cell size is considered to have numerous effects on the physiology and role of algae in planktonic communities (Finkel et al. 2010), which influenced the present classification scheme in two different aspects. On the one hand, there is a difference in the sensitivity to grazing pressure between the groups of large cells, colonies or filaments and the ones with smaller dimensions. On the other hand, there was high variability in terms of $s / v$ within certain groups, which was partly caused by the fact that we did not create categories for this variable. Our reason for that was based on the assumption that while cell size is a fundamental factor in determining grazing susceptibility, a similarly strong relationship does not necessarily hold true for $s / v$ and metabolic efficiency, since metabolic activity is additionally influenced by a range of other factors. This complexity of relationships hinders the division of $s / v$ into categories that could be clearly linked to distinct ranges of metabolic efficiency. This consideration has resulted in a classification where the size-selective effect of grazing is expected to be more important than the role of $s / v$ in affecting processes like photosynthesis or resource acquisition.

Despite the variable species-specific $s / v$ values, Group 6 (small unicells) represents an adequately uniform fraction of the community, since it mainly consists of species of the picoplankton size range with particularly high $s / v$ ratios of 4-6.4. The functional significance of high $s / v$ in this group is supported by the finding of Vörös (1991), who pointed out that the 
observed higher biomass-specific carbon uptake of this size fraction suggests faster metabolism rates, since in Lake Balaton their contribution to total primary production is greater than their share in total phytoplankton biomass. This group serves also as an example highlighting the technical drawbacks of species diversity. In most cases picophytoplankton cannot be identified on the species or genus level with traditional microscopic analysis (Callieri 2008), thus the use of diversity indices based on species number and abundance can be inappropriate and misleading in communities with various taxa in the pico size range.

Diatoms constitute a considerable proportion of the phytoplankton species pool in Lake Balaton, which would necessitate the inclusion of silica demand as a species trait during classification, as it has been suggested by others (Weithoff 2003; Longhi and Beisner 2010). However, silica has not been found to be a limiting nutrient in the lake (Istvánovics et al. 1986; Honti et al. 2007), making the consideration of this trait unnecessary for the classification presented here. Considering all the above, the described functional groups have the potential to provide a coarse, but simple alternative for determining and interpreting phytoplankton diversity patterns in Lake Balaton. On the other hand, the example of silica demand also suggests that studying aquatic habitats with various characteristics can generate to a certain extent different classification schemes.

Sorting species into groups with different functional attributes may be a starting point to better understand community-level processes, since changes in biodiversity alter the distribution of species traits, which in turn influence ecosystem functioning (Chapin et al. 2000). Thus the temporal distribution of the groups determined in our analysis makes possible to stress the importance of the selected traits in the phytoplankton community on a temporary basis. This is well demonstrated in the large cyanobacterial filaments and colonies of group 7, which regularly dominated the community of the western basin during the late summer biomass maxima (Fig. 5). The most abundant members of this group are $\mathrm{N}_{2}$-fixing cyanobacteria, which have been shown to provide up to $30 \%$ of the daily nitrogen input in this part of the year (Présing et al. 2001), emphasizing the importance of $\mathrm{N}_{2}$-fixing as a functionally relevant attribute considerably 
influencing ecosystem processes, particularly nutrient cycling. Présing et al. (2008) found that in Lake Balaton the quantity of nitrogen in the water column and that originating from ammonium regeneration in the sediment is not adequate to meet nitrogen demand in late summer, which consequently limits phytoplankton standing crop. This situation confers competitive advantage on $\mathrm{N}_{2}$-fixing cyanobacteria, thus the steep decline in functional group diversity in the western basin not only coincides with late-summer blooms but also hints at nitrogen limitation. Another important trait of $\mathrm{N}_{2}$-fixing cyanobacteria is their filamentous form and size, which can directly affect their edibility. Zooplankton grazing on filamentous cyanobacteria seems to be species-specific (e.g. Epp 1996), and increases in their biomass are likely to cause shifts in zooplankton size structure (Ghadouani et al. 2006) as well as trigger behavioural and morphological responses (Bednarska and Dawidowicz 2007) eventually contributing to changes in ecosystem functioning.

As shown in Fig. 4C and 5C, medium-sized non-motile cells (group 2) were also dominant in certain periods in both basins, however, it showed no or negligible correlation with environmental variables (Table 2). The lack of significant correlation, which was also observed in the case of small unicells (group 6), may suggest that top-down control is also a determining factor shaping the temporal pattern of these groups. Some studies have pointed out the importance of zooplankton grazing on smaller phytoplankton $(<30-35 \mu \mathrm{m})$ (e.g. Lampert et al. 1986, Cottingham 1999), while picophytoplankton can serve as a major food source for nanoflagellates and ciliates (Callieri et al. 2002, Tarbe et al. 2011), although the effect of grazing on phytoplankton size structure is too complex to draw straightforward conclusions from our observations, various groups of the zooplankton appear to have different preferences for prey size (Bergquist et al. 1985, Sommer et al. 2001). Apart from this, the above assumptions are good examples of the exploratory power of functional approaches, throwing light on unknown segments in the web of processes and relationships within an ecosystem and raising further research questions and hypotheses.

\section{Diversity changes in Lake Balaton}


Diversity studies on the phytoplankton of Lake Balaton have long been based on taxonomic approaches (Entz et al. 1937; Padisák et al. 2005), but a substantial amount of work has as well been intended to explain the observed compositional patterns from various points of view somehow linked to community functioning. Main contributions to this effort include the adoption of Connell's intermediate disturbance hypothesis (Connell 1978), which highlighted the role of storms in regulating summer phytoplankton succession (Padisák et al. 1988) and diversity (Padisák 1993), and the application of functional groups suggested by Reynolds et al. (2002) for monitoring the ecological status of the lake (Padisák et al. 2006). Our results contribute to the earlier research efforts with the finding that certain characteristics of phytoplankton diversity are liable to remaining hidden without the use of a classification based on functional traits.

Despite the similar shape of the curves in Fig. 4B and 5B there are considerable differences at certain times between the temporal changes of species diversity and functional group diversity. This is caused by the fact that the abundances of species and those of the traits they possess can yield different patterns. The most striking divergence in the western basin at the end of summer 2006 is in connection with the eutrophic conditions typical of this part of the lake. Previous studies found neither a clearly discernible relationship between phytoplankton species diversity and total biomass (Vörös and Németh 1980), nor considerable trends along the west-east trophic gradient (Padisák et al. 2005). The differences between species diversity and functional group diversity revealed in our study, considering $\mathrm{N}_{2}$-fixing cyanobacteria in particular, have been caused by the fact that the observed biomass peak in the summer phytoplankton was due to the simultaneous dominance of several different species with basically the same or very similar functional traits. During these periods, when the decrease in the evenness of functional groups results in a dramatic decline in their diversity, eutrophic conditions can be characterized not only by the phytoplankton blooms but also by the dwindling set of traits related to the functional responses and effects of the phytoplankton community during these blooms. During a biomass peak of filamentous cyanobacteria in Lake Balaton the average filtering rate of crustacean zooplankton was found to decrease by $70 \%$ (Zánkai 
and Ponyi 1986), which is a good example showing what consequences a sudden shift in the diversity of traits can have in community processes. In such cases the informative value of species diversity can be remarkably low, providing no further basis for using our species-level phytoplankton data to gain more insight into community structure and functioning. Our conclusion agrees well with those of Longhi and Beisner (2010) and Vogt et al. (2010) with respect to phytoplankton communities and benthic diatoms in Canadian lakes. In the present study this means that eutrophication, while not necessarily causing decline in the diversity and evenness of species, does clearly affect the distribution of species traits.

Smaller differences between the temporal changes in species and functional group diversity can also refer to absolutely different aspects of biodiversity. Such an example can be seen between October and December 2005 in the eastern basin, when the diversity of functional groups showed a decline, while species diversity exhibited a peak in November. From October to November the number of functional groups decreased, large phagotrophic and non-phagotrophic flagellates (Groups 3 and 4) and medium-sized cyanobacteria (Group 8) were absent from the community, on the other hand, there was only a slight drop in species richness with a considerable increase in species evenness. In this case functional group diversity truly meant the temporary lack of specific trait combinations, while species diversity produced the illusion of a rich community. In December both diversity indices showed a marked decline mainly because of decreasing evenness brought about by the dominance of medium-sized, non-motile cells (Group 2). Species dominance within this group underwent a conspicuous shift in centric diatoms from Cyclotella ocellata in October to Cyclotella comta in December. In November the difference in the abundance of these species was considerably smaller than on the preceding and following date, and this was also true for most of the species in other functional groups, all of which contributed to a more even species distribution and increasing species diversity. By December Cyclotella comta became the dominant species of the whole phytoplankton community. Both Cyclotella species possess similar functional traits, from which we can come to the conclusion that such a peak in species diversity could be of lesser 
importance in a functional sense. We can draw the same conclusion when looking at the temporal changes of diversity in the western basin in winter 2005/2006.

The results of the correlation analysis (Table 1) and the principal component analysis (Fig. 7) show that there is a significant inverse relationship between functional group diversity and phytoplankton biomass, which is mostly due to the abovementioned low-diversity biomass peaks of the western basin. From this relationship we may assume that trophic state has the potential to have profound influence on the temporal trends in diversity, on the other hand we found no link with total phosphorus concentration, which is also a widely used indicator of trophic conditions. The reason for this is mainly the fact that $\mathrm{TP}$ is not applicable as such an indicator to Lake Balaton, because a substantial part of it is attached to sediments, which are regularly resuspended as a consequence of wind-induced mixing. This particularity of this shallow lake manifests itself in the close connection between TP and total suspended sediments (Fig. 2), and has already been pointed out in earlier studies (e.g. Herodek and Istvánovics 1986). A part of this particulate phosphorus pool is potentially mobile, thus sediment resuspension may cause desorption, which is supposed to be an important source of phosphorus supply (Istvánovics 2004). However, the estimated amount of mobile phosphorus shows a decreasing trend since eutrophication was reversed in the lake (Istvánovics et al. 2007), and revealing any putative effect of this phosphorus fraction would have required substantially higher sampling frequency impracticable in a long-term study on phytoplankton diversity patterns. The lack of a significant correlation of TSS and $\mathrm{K}_{\mathrm{d}}$ with diversity may refer to more complex phenomena, e.g. a unimodal relationship, but the dot plots of these variables did not provide any discernible pattern that could indicate unimodality.

Low temperatures and lower ambient light intensity in winter generally caused low biomass and diversity in the phytoplankton, and this decline in diversity meant a decrease in the number of both species and functional groups. Winter samples usually lacked large-celled flagellates and large and medium-sized cyanobacterial filaments and colonies, on the other hand middle-sized flagellates reached their maximum biomass contribution between late autumn and mid-spring. Small-sized 
picophytoplankton, although not only characteristic for low temperatures, also had some considerable relative abundance values in that period, particularly in the eutrophic western basin. This putative effect of temperature on the annual pattern of the size structure might have several direct and indirect causes, such as changes in grazing pressure, pointing out the necessity of further research efforts on this field, since phytoplankton cell size can influence food web structure and the biogeochemical cycling of nutrients (see Finkel et al. (2010) for a review). Low light intensity in winter could also have contributed to the observed decline in biomass and diversity, however, distinguishing between the impact of temperature and light availability in this respect is a difficult task because of the similar annual cycle of both factors.

The overall effect of temperature on functional group diversity becomes more apparent in the multidimensional space of all the variables considered, showing that the variability of diversity in the eastern basin is closely related to changes in temperature. Our conclusion is in agreement with those of Padisák et al. (2010), who stressed the importance of physical forcing (including low temperature as a major factor) in shaping phytoplankton biomass and composition in winter. During these periods functional group diversity was low in both basins, although diversity in the western part showed somewhat higher variability. From early spring toward the summer months rising temperature and light intensity provide more favourable conditions for the community, which eventually adds up to a higher diversity of species with various trait combinations. Higher nutrient loads characteristic for eutrophic waters increase the probability of abrupt shifts in composition leading to the dominance of certain groups, such as filamentous cyanobacteria in the western basin. When these blooms occur, the effects phytoplankton can exert on nutrient cycling or food web interactions is constrained to those determined by the functional traits of the group detailed previously. This train of thought leads us to the presumption that besides increasing the variability of phytoplankton biomass, eutrophication is also likely to increase the temporal variance of trait composition and distribution in the community, which in turn enhances the annual fluctuation in its effects on the aquatic environment. Above a certain threshold value in biomass $\left(\sim 4500-5000 \mu \mathrm{g} \mathrm{L}^{-1}\right)$ 
the dominance of certain functional groups with a limited range of trait values can consequently lead to dramatic changes, which normally do not occur in a mesotrophic state. This assumption may be an important point in the light of our results that grabs the essence of using functional diversity indices instead of merely determining taxonomic diversity in phytoplankton communities, and thus has the potential to highlight fundamental points for further research and serve as a basis to address more expedient questions in future studies on phytoplankton ecology.

\section{Acknowledgements}

This research was financially supported by the Hungarian Scientific Research Fund (NKTHOTKA A08-2 CNK 801400, OTKA K73369). The authors are gratefully indebted to Balázs Németh for technical assistance.

\section{References}

Bahr LM (1982) Functional taxonomy: an immodest proposal. Ecol Model 15:211-233

Barnett AJ, Finlay K, Beisner BE (2007) Functional diversity of crustacean zooplankton communities: towards a trait-based classification. Freshwater Biol 52:796-813

Bednarska A, Dawidowicz P (2007) Change in filter-screen morphology and depth selection: Uncoupled responses of Daphnia to the presence of filamentous cyanobacteria. Limnol Oceanogr 52:2358-2363

Bergquist AM, Carpenter SR, Latino JC (1985) Shifts in phytoplankton size structure and community composition during grazing by contrasting zooplankton assemblages. Limnol Oceanogr 30:1037-1045

Callieri C, Karjalainen SM, Passoni S (2002) Grazing by ciliates and heterotrophic nanoflagellates on picocyanobacteria in Lago Maggiore, Italy. J Plankton Res 24:785-796 
Callieri C (2008) Picophytoplankton in freshwater ecosystems: the importance of small-sized phototrophs. Freshwater Reviews 1:1-28

Chapin III FS, Zavaleta ES, Eviner VT, et al (2000) Consequences of changing biodiversity. Nature 405:234-242

Connell JH (1978) Diversity in tropical rain forests and coral reefs. Science 199:1302-1310

Cottingham KL (1999) Nutrients and zooplankton as multiple stressors of phytoplankton communities: Evidence from size structure. Limnol Oceanogr 44:810-827

Duarte P, Macedo MF, Cancela da Fonseca L (2006) The relationship between phytoplankton diversity and community function in a coastal lagoon. Hydrobiologia 555:3-18

Entz G, Kottász J, Sebestyén O (1937) Quantitative Untersuchungen am Bioseston des Balatons. Annal Biol Tihany 9:1-152

Epp GT (1996) Grazing on filamentous cyanobacteria by Daphnia pulicaria. Limnol Oceanogr 41:560-567

Erős T, Heino J, Schmera D, Rask M (2009) Characterising functional trait diversity and traitenvironment relationships in fish assemblages of boreal lakes. Freshwater Biol 54:1788-1803

Finkel ZV (2001) Light absorption and size scaling of light-limited metabolism in marine diatoms. Limnol Oceanogr 46:86-94

Finkel ZV, Beardall J, Flynn KJ, Quigg A, Rees TAV, Raven JA (2010) Phytoplankton in a changing world: cell size and elemental stoichiometry. J Plankton Res 32:119-137

Frost BW (1972) Effects of size and concentration of food particles on the feeding behavior of the marine planktonic copepod Calanus pacificus. Limnol Oceanogr 17:805-815

Gaedke U (1998) Functional and taxonomical properties of the phytoplankton community of large and deep Lake Constance: Interannual variability and response to re-oligotrophication (19791993). Arch Hydrobiol Spec Issues: Advanc Limnol 53:119-141

Gales ME JR., Julian EC, Kroner RC (1966) Method for quantitative determination of total phosphorus in water. J Amer Water Works Assoc 58:1363-1368 
Ghadouani A, Pinel-Alloul B, Prepas EE (2006) Could increased cyanobacterial biomass following forest harvesting cause a reduction in zooplankton body size structure? Can J Fish Aquat Sci $63: 2308-2317$

Gower JC (1971) A general coefficient of similarity and some of its properties. Biometrics 27:857874

Graham LE, Graham JM, Wilcox LW (2009) Algae. Benjamin Cummings, San Francisco

Hajnal É, Padisák J (2008) Analysis of long-term ecological status of Lake Balaton based on the ALMOBAL phytoplankton database. Hydrobiologia 599:227-237

Hector A, Schmid B, Beierkuhnlein C et al (1999) Plant diversity and productivity experiments in European grasslands. Science 286:1123-1127

Hein M, Pedersen MF, Sand-Jensen K (1995) Size-dependent nitrogen uptake in micro- and macroalgae. Mar Ecol Prog Ser 118:247-253

Herodek S, Istvánovics V (1986) Mobility of phosphorus fractions in the sediments of Lake Balaton. Hydrobiologia 135:149-154

Hillebrand H, Dürselen C-D, Kirschtel D, Pollingher U, Zohary T (1999) Biovolume calculation for pelagic and benthic microalgae. J Phycol 35:403-424

Honti M, Istvánovics V, Osztoics, A (2007) Stability and change of phytoplankton communities in a highly dynamic environment - the case of large, shallow Lake Balaton (Hungary). Hydrobiologia 581:225-240

Istvánovics V, Vörös L, Herodek S, G.-Tóth L, Tátrai I (1986) Changes of phosphorus and nitrogen limitation in enriched lake enclosures. Limnol Oceanogr 31:798-811

Istvánovics V, Osztoics A, Honti M (2004) Dynamics and ecological significance of daily internal load of phosphorus in shallow Lake Balaton, Hungary. Freshwater Biol 49:232-252

Istvánovics V, Clement A, Somlyódy L, Specziár A, G.-Tóth L, Padisák J (2007) Updating water quality targets for shallow Lake Balaton (Hungary), recovering from eutrophication. Hydrobiologia 581:305-318 
Jacobsen BA, Simonsen P (1993) Disturbance events affecting phytoplankton biomass, composition and species diversity in a shallow, eutrophic, temperate lake. Hydrobiologia 249:9-14

Kagami M, Urabe J (2001) Phytoplankton growth rate as a function of cell size: an experimental test in Lake Biwa. Limnology 2:111-117

Krebs CJ (1998) Ecological Methodology. Harper \& Row, New York

Lampert W, Fleckner W, Rai H, Taylor BE (1986) Phytoplankton control by grazing zooplankton: A study on the spring clear-water phase. Limnol Oceanogr 31:478-490

Litchman E, Klausmeier CA (2008) Trait-based community ecology of phytoplankton. Annu Rev Ecol Evol Syst 39:615-639

Longhi ML, Beisner BE (2010) Patterns in taxonomic and functional diversity of lake phytoplankton. Freshwater Biol 55:1349-1366

Lonsdale DJ, Cosper EM, Doall M (1996) Effects of zooplankton grazing on phytoplankton sizestructure and biomass in the lower Hudson River estuary. Estuaries 19:874-889

MacIsaac EA, Stockner JG (1993) Enumeration of phototrophic picoplankton by autofluorescence microscopy. In: Kemp PF, Sherr BF, Sherr EB, Cole JJ (eds) Handbook of methods in aquatic microbial ecology. Lewis Publishers, Boca Raton, pp 187-197

Padisák J (1993) The influence of different disturbance frequencies on the species richness, diversity and equitability of phytoplankton in shallow lakes. Hydrobiologia 249:135-156

Padisák J, Szabó I (1997) Botanikai kutatások a Balatonon: alacsony-és magasabbrendű növények. In: Salánki J, Nemcsók, J (eds) A Balatonkutatás eredményei 1981-1996. MTA Veszprémi Területi Bizottsága és a Miniszterelnöki Hivatal Balatoni Titkársága, Veszprém, pp 97-135

Padisák J, Reynolds CS (1998) Selection of phytoplankton associations in Lake Balaton, Hungary, in response to eutrophication and restoration measures, with special reference to the cyanoprokaryotes. Hydrobiologia 191:249-254 
Padisák J, G.-Tóth L, Rajczy M (1988) The role of storms in the summer succession of the phytoplankton community in a shallow lake (Lake Balaton, Hungary). J Plankton Res 10:249_ 265

Padisák J, Crossetti LO, Naselli-Flores L (2009) Use and misuse in the application of the phytoplankton functional classification: a critical review with updates. Hydrobiologia 621:1-19

Padisák J, Soróczki Pintér É, Hajnal É, Zámbóné Doma Zs (2005) A balatoni fitoplankton tér- és időbeli mintázata 2004-ben. In: Mahunka S, Banczerowski J (eds) A Balaton kutatásának 2004. évi eredményei. MTA, Budapest, pp 16-26

Padisák J, Borics G, Grigorszky I, Soróczki-Pintér É (2006) Use of phytoplankton assemblages for monitoring ecological status of lakes within the Water Framework Directive: the assemblage index. Hydrobiologia 553:1-14

Padisák, J, Hajnal É, Naselli-Flores L, Dokulil MT, Nõges P, Zohary T (2010). Convergence and divergence in organization of phytoplankton communities under various regimes of physical and biological control. Hydrobiologia 639:205-220

Paredes MA, Montecino V (2011) Size diversity as an expression of phytoplankton community structure and the identification of its patterns on the scale of fjords and channels. Cont Shelf Res $31: 272-281$

Perissinotto R (1992) Mesozooplankton size-selectivity and grazing impact on the phytoplankton community of the Prince Edward Archipelago (Southern Ocean). Mar Ecol Prog Ser 79:243-258

Petchey OL, Gaston KJ (2006) Functional diversity: back to basics and looking forward. Ecol Lett 9:741-758

Podani J (1999) Extending Gower's general coefficient of similarity to ordinal characters. Taxon 48:331-340

Présing M, Herodek S, Preston T, Vörös L (2001) Nitrogen uptake and the importance of internal nitrogen loading in Lake Balaton. Freshwater Biol 46:125-139 
Présing M, Preston T, Takátsy A, Sprőber P, W Kovács A, Vörös L, Kenesi Gy, Kóbor I (2008) Phytoplankton nitrogen demand and the significance of internal and external nitrogen sources in a large shallow lake (Lake Balaton, Hungary). Hydrobiologia 599:87-95

Raven JA (1997) Phagotrophy in phototrophs. Limnol Oceanogr 42:198-205

Reynolds CS, Huszar V, Kruk C, Naselli-Flores L, Melo S (2002) Towards a functional classification of the freshwater phytoplankton. J Plankton Res 24:417-428

Rocap G, Larimer FW, Lamerdin J et al (2003) Genome divergence in two Prochlorococcus ecotypes reflects oceanic niche differentiation. Nature 424:1042-1047

Sommer U, Sommer F, Santer B, Jamieson C, Boersma M, Becker C, Hansen T (2001) Complementary impact of copepods and cladocerans on phytoplankton. Ecol Lett 4:545-550

Tarbe A-L, Unrein F, Stenuite S, Pirlot S, Sarmento H, Sinyinza D, Descy J-P (2011) Protist herbivory: a key pathway in the pelagic food web of Lake Tanganyika. Microb Ecol 62:314-323

Tilman D, Knops J, Wedin D, Reich P, Ritchie M, Siemann E (1997) The influence of functional diversity and composition on ecosystem processes. Science 277:1300-1302

Utermöhl H (1958) Zur Vervollkommung der quantitativen Phytoplankton-Methodik. Mitt Int Ver Limnol 9:1-38

Vogt RJ, Beisner BE, Prairie YT (2010) Functional diversity is positively associated with biomass for lake diatoms. Freshwater Biol 55:1636-1646

Vörös L (1991) Importance of picoplankton in Hungarian shallow lakes. Verh Internat Verein Limnol 24:984-988

Vörös L, Németh J (1980) Changes in the structure of phytoplankton in Lake Balaton as a result of eutrophication. In: Dokulil M, Metz H, Jewson D (eds) Developments in Hydrobiology Vol 3 Shallow Lakes - Contributions to their Limnology. Dr. W. Junk b.v. Publishers, The Hague, pp 73-79

Vörös L, Nagy Göde P (1993) Long term changes of phytoplankton in Lake Balaton (Hungary). Verh Internat Verein Limnol 25:682-686 
Weithoff G (2003) The concepts of 'plant functional types' and 'functional diversity' in lake phytoplankton - a new understanding of phytoplankton ecology? Freshwater Biol, 48:16691675.

Weithoff G, Walz N, Gaedke U (2001) The intermediate disturbance hypothesis - species diversity or functional diversity? J Plankton Res 23:1147-1155

Wellburn AR (1994) The spectral determination of chlorophylls $a$ and $b$, as well as total carotenoids, using various solvents with spectrophotometers of different resolution. J Plant Physiol 144:307-313

Zánkai PN, Ponyi JE (1986) Composition, density and feeding of crustacean zooplankton community in a shallow, temperate lake (Lake Balaton, Hungary). Hydrobiologia 135:131-147 
Table 1 Pearson's correlation coefficients between diversity and evenness indices and the measured variables in Lake Balaton based on data collected in 2005-2006 and 2008-2009 (p < 0.05). H: species diversity; $J$ : evenness of species; $H_{f}$ : functional group diversity; $J_{f}$ : evenness of functional groups. Cells with no significant correlation were left blank.

\begin{tabular}{lcccc}
\hline & $H$ & $J$ & $H_{f}$ & $J_{f}$ \\
\hline Total biomass & & -0.284 & -0.293 & -0.571 \\
Chlorophyll $a$ & & -0.202 & -0.336 & -0.576 \\
Temperature (T) & 0.424 & & 0.458 & \\
Total suspended solid (TSS) & & & \\
Total phosphorus (TP) & 0.259 & & & -0.244 \\
Vertical extinction coefficient $\left(\mathrm{K}_{\mathrm{d}}\right)$ & & & \\
\hline
\end{tabular}

Table 2 Pearson's correlation coefficients between the biomass of phytoplankton functional groups and the measured variables in Lake Balaton based on data collected in 2005-2006 and 2008-2009 (p $<0.05)$. Numbers representing the eight functional groups are detailed in the text. Cells with no significant correlation were left blank.

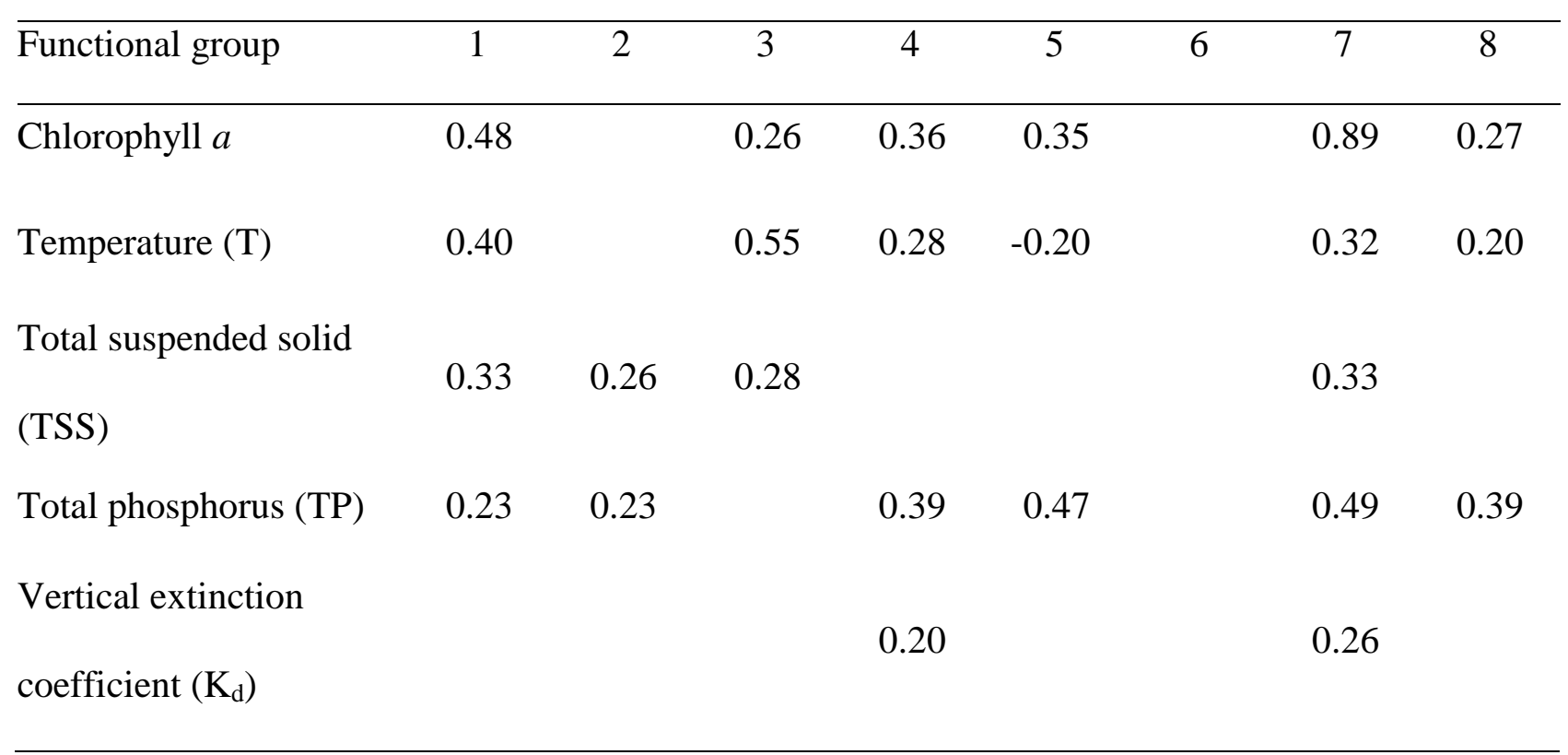



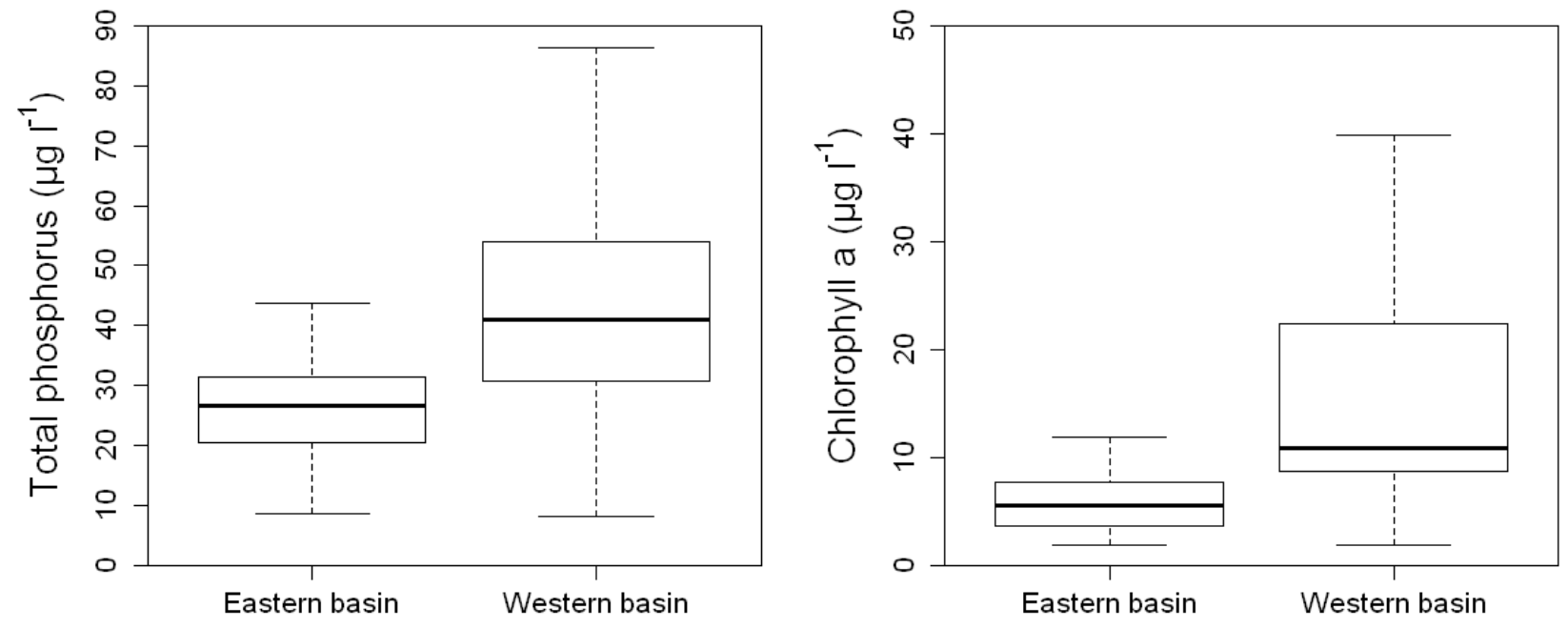

Fig. 1 Boxplots of total phosphorus (TP) and chlorophyll $a$ concentration in the eastern and western basin of Lake Balaton measured between 2005-2006 and 2008-2009

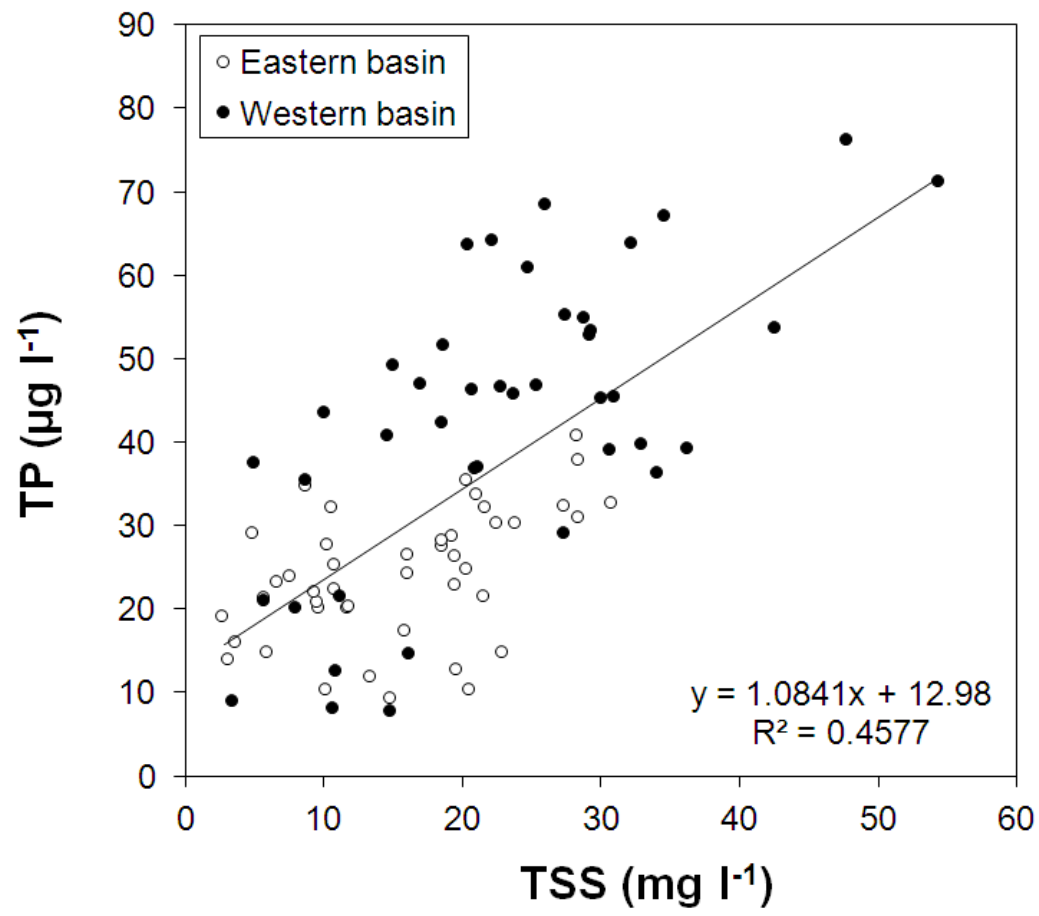

Fig. 2 Total phosphorus concentration (TP) plotted versus total suspended solids content (TSS) in Lake Balaton based on data collected in 2005-2006 and 2008-2009 


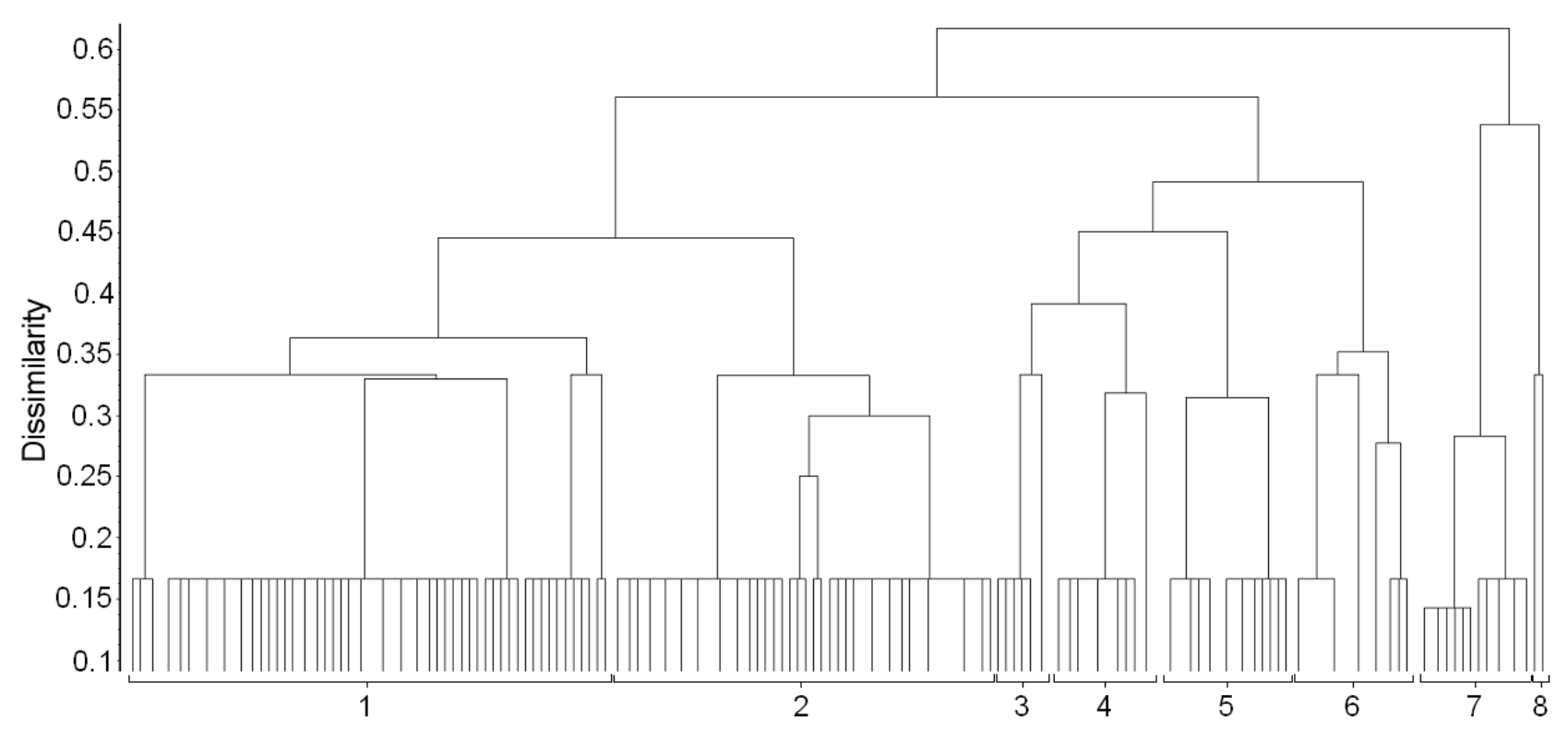

Fig. 3 Dendrogram of the species found in the phytoplankton of Lake Balaton in 2005-2006 and 2008-2009 after cluster analysis using the selected species traits, numbers at the bottom represent functional groups of phytoplankton described in the text 

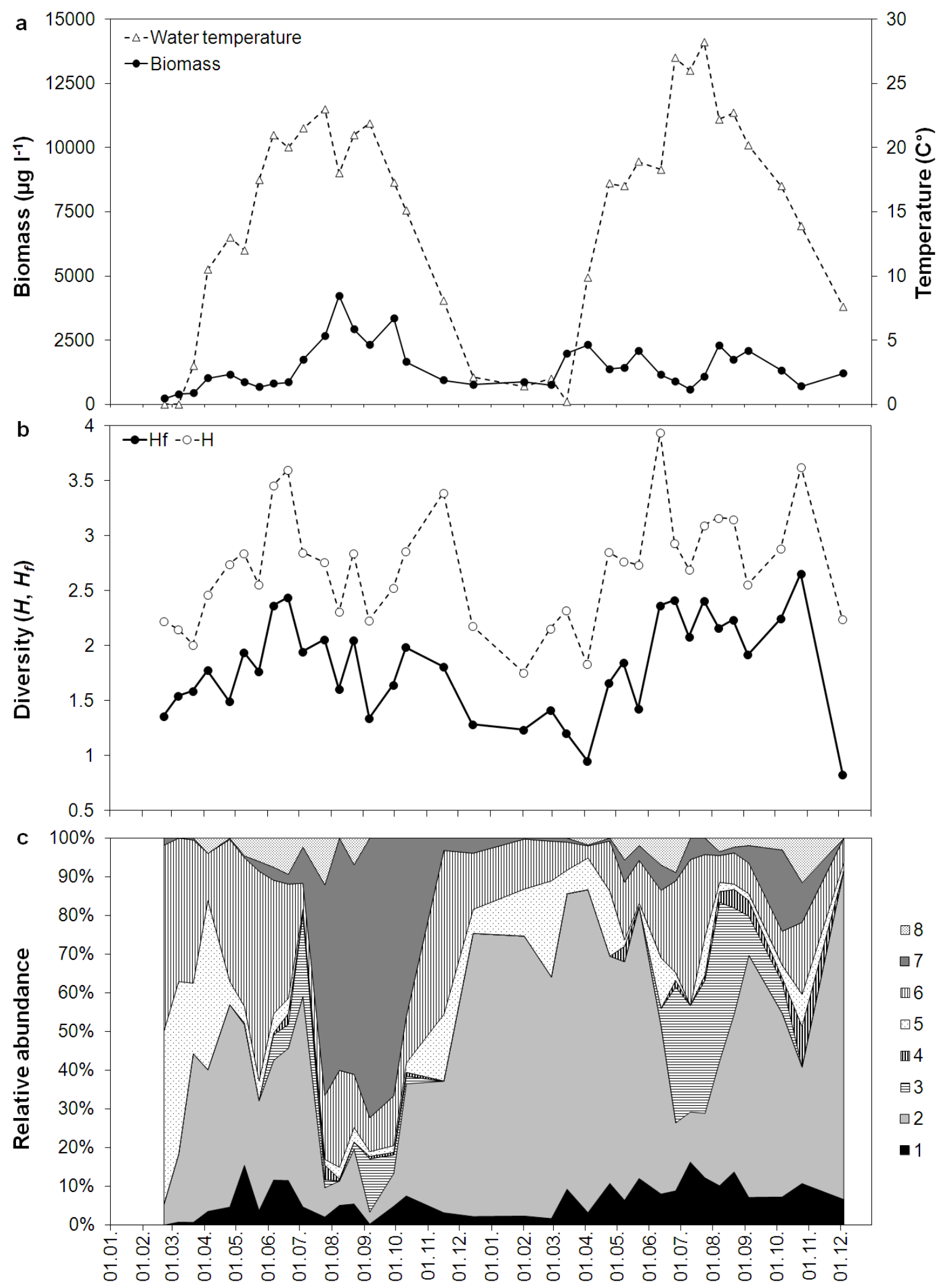

Fig. 4 Temporal changes of water temperature, total phytoplankton biomass (a), species $(H)$ and functional group diversity $\left(H_{f}\right)$ (b), and the relative abundance of functional groups (c) in the eastern basin of Lake Balaton in 2005-2006. Numbers in Fig. C represent the eight functional groups of phytoplankton described in the text 

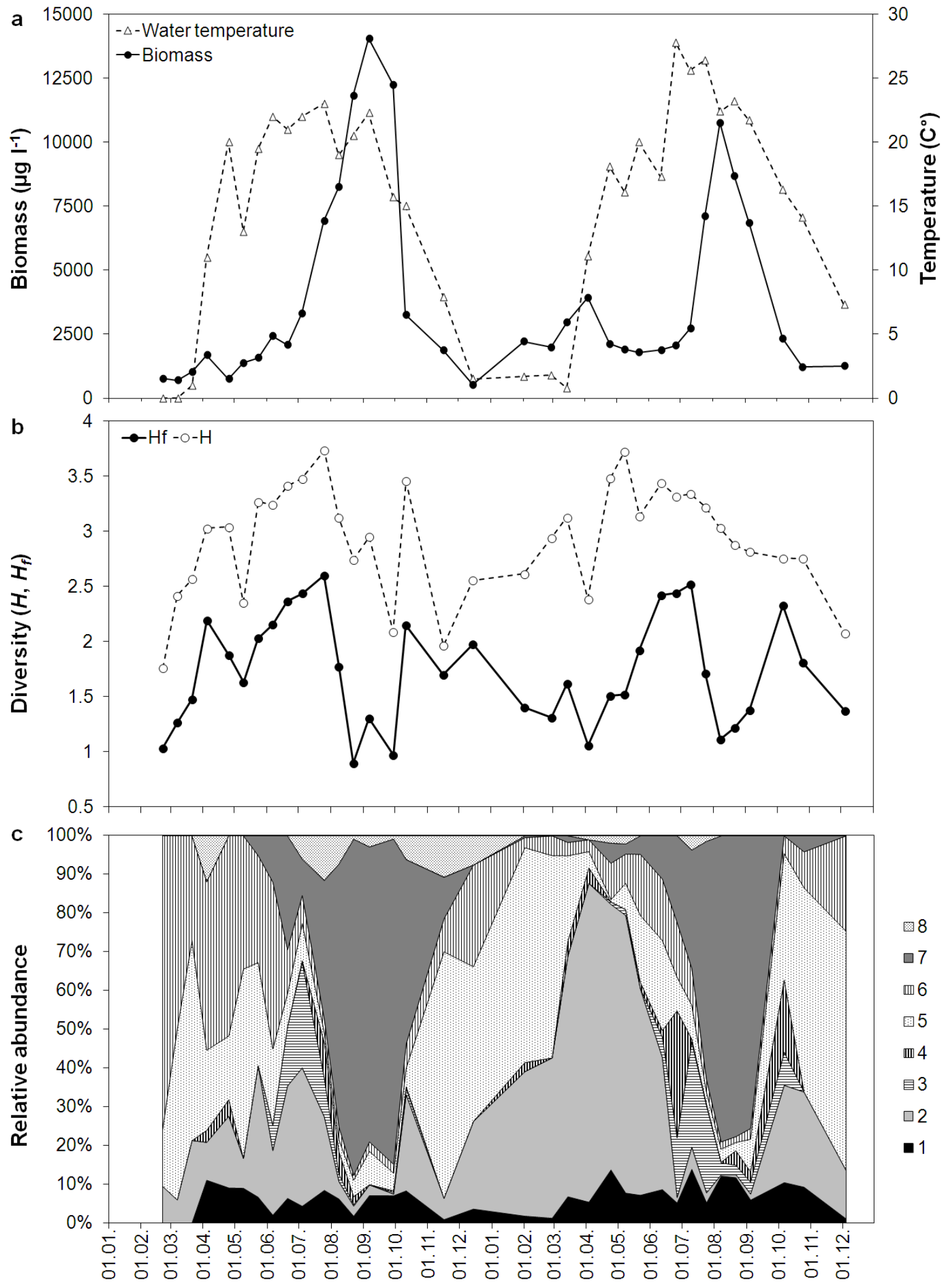

Fig. 5 Temporal changes of water temperature, total phytoplankton biomass (a), species $(H)$ and functional group diversity $\left(H_{f}\right)$ (b), and the relative abundance of functional groups (c) in the western basin of Lake Balaton in 2005-2006. Numbers in Fig. C represent the eight functional groups of phytoplankton described in the text 

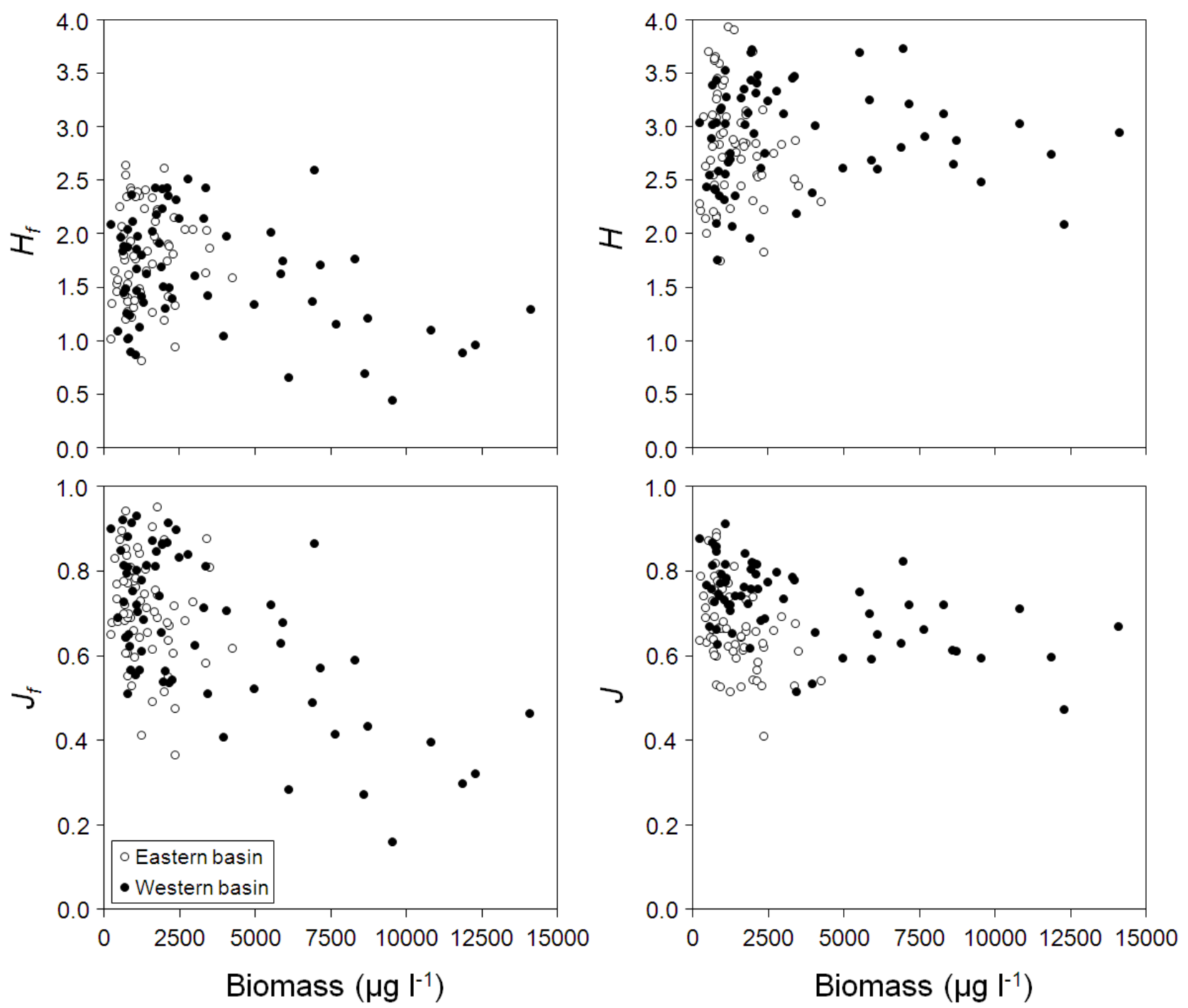

Fig. 6 Phytoplankton species diversity $(H)$ and evenness $(J)$ and functional group diversity $\left(H_{f}\right)$ and evenness $\left(J_{f}\right)$ plotted versus total biomass in the eastern and western basin of Lake Balaton based on data collected in 2005-2006 and 2008-2009 


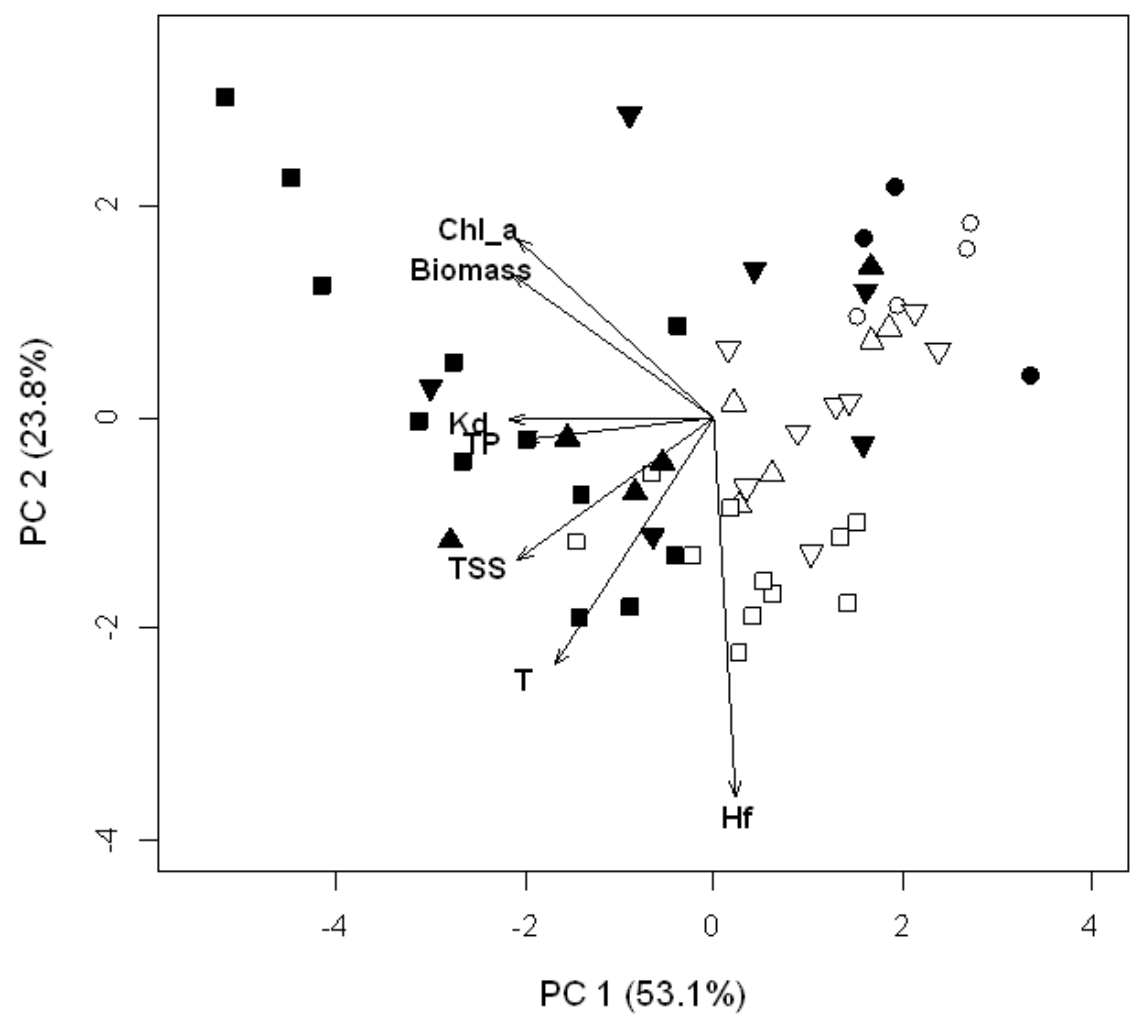

Fig. 7 PCA biplot of the measured variables and functional group diversity (Hf) in Lake Balaton. $\mathrm{K}_{\mathrm{d}}$ : vertical extinction coefficient; TP: total phosphorus concentration; TSS: total suspended solids; T: temperature; Biomass: total phytoplankton biomass; Chl a: chlorophyll $a$ concentration. Open symbols represent the eastern basin, solid symbols represent the western basin. Circles: winter samples; triangles: spring samples; squares: summer samples; reversed triangles: autumn samples 